\title{
PENGAJARAN SASTRA BERBASIS EXPERIENCE LEARNING
}

\author{
Suwardi Endraswara \\ Universitas Negeri Yogyakarta \\ Email: suwardi_Endraswara@yahoo.com
}

\begin{abstract}
Abstrak: Tulisan ini bermaksud memberikan pemahaman terhadap pembelajaran sastra gaya baru. Pembelajaran yang inovatif ditandai oleh perubahan paradigma, yang semula menekankan hafalan, berubah ke arah pemberian pengalaman hidup. Pengajaran sastra yang mendewakan guru sebagai superior, sudah tidak saatnya lagi. Guru dan siswa sudah saatnya mengubah diri ke arah sharing pengalaman hidup. Pengajaran sastra berbasis pengalaman bertujuan memberikan warna baru agar sastra tetap dihargai oleh siswa. Sastra adalah karya yang memuat aneka pengalaman. Oleh sebab itu, dalam pembelajaran diharapkan ada kontak atau komunikasi intensif. Komunikasi sastra tersebut terjadi ketika siswa mampu menafsirkan dan menimba pengalaman. Itulah salah satu bentuk pengalaman yang menggoda dalam pembelajaran sastra. Perubahan kultur pembelajaran teoritik kea rah pemberian pengalaman akan dapat menjajdi jembatan penyemaian pendidikan karakter lewat cipta sastra.
\end{abstract}

Kata kunci: pembelajaran, pengalaman, dan hidup

Abstract: The paper is to give overviewes on new literary teaching style. The innovative learning is noted by the changing paradigm from giving strengths on memorizing to life experience. Liteary teaching which put the teacher as a superior, is out dated. Teacher and students are now changing to share life experiences. Excperience based literary teaching is aimed at giving a new horizon to sustain the life of literary teaching in order to be respected. Literature is a work which comprises various kinds of experiences. Therefore, in the process of learning and teaching, it is hoped that there is an intensive communication between teacher and students. Literary communication happens when students are able to interpret and to live the experience. That is one of the enchanting experiences in literary teaching. The changing paradigm from theoretical learning and teaching to sharing experience will be able to bridge the gap in character building of education through literary experiencing.

Keywords: learning, experience, life

\section{Pendahuluan}

Sastra itu kaya pengalaman hidup. Maka pembelajaran sastra sudah selayaknya digiring menuju penyemaian experiencelearning. Experience-learning adalah rasionalitas pembelajaran sastra yang mengajak siswa menghayati pengalaman hidup. Rasionalisasi adalah pertimbangan akal, untuk mendudukkan persoalan pengajaran sastra itu dalam posisi yang strategis. Rasionalisme menyangkut berbagai aspek yang terkait dengan pengajaran sastra, seperti bahan, guru, strategi, dan sebagainya. Tanpa pemahaman yang rasional, orang selalu menginginkan berbagai hal akan diajarkan. Pertimbangan akal, justru akan menolong eksistensi pengajaran sastra yang sampai detik ini semakin terpuruk.

Huck Dkk (1987:12) mengajukan tesis rasional pengajaran sastra yang patut diperhatikan. Menurut dia, sastra diajarkan 
memang harus ke arah siswa mampu memahami nilai-nilai humanitas. Aktivitas siswa, perlu digiring menjadi orang yang manusiawi. Inilah inti dari pendidikan karakter dalam sastra. Berolah sastra untuk mengubah aksi kehewanan menuju kehumanitasan jauh lebih mulia. Oleh karena, sadar atau tidak dalam diri manusia ada dua watak yang hamper sulit diubah, yaitu (1) watak hewan, mulai pucuk rambut sampai ujung kaki, nuansa hewan ada dalam diri manusia (2) watak tumbuhan, seperti gadung, gembili, lung, alang-alang, dan lain-lain, juga ada dalam diri manusia. Rasanya, manusia sebagai makhluk carnivore dan herbivore, telah bersinergis dengan wataknya. Itulah sebabnya, pengajaran sastra berkewajiban menghaluskan watak itu.

Pembelajaran sastra secara teoritik dapat menyumbangkan pemikiran pada siswa untuk memberikan penghargaan (valuing) terhadap cipta sastra. Lewat analisis yang mendalam dan cermat siswa dapat memahami cirri-iri mendasar karya sastra. Pertimbangan anjutnya, siswa mampu memahami kategori membedakan antara fiksi dan non-fiksi. Fiksi itu karya yang penuh daya imajinasi. Sebut saja cerita bersambung Api di Bukit Menoreh karya S.H. Mintardja, jelas merupakan wujud roman sejarah, yang dibumbui fiksi historis.

Dengan demikian sastra berisi gambaran kehidupan seseorang tentang diri sendiri, sejarah, dan tempat siswa di alam semesta. Seolah-olah siswa dapat mengalami kehidupan langsung seperti dalam karya sastra. Siswa perlu diajak untuk melakukan aktivitas sastra, yang menuju pencapaian karakter mulia. Gagasan Dir John Herschel (Huck, Dkk. 1987:12) menyatakan tentang nilai karakter yang ada dalam sastra semestinya diberikan pada siswa. Menurut dia siswa sentuhan rasa untuk membaca sastra agar memperoleh (1) sastra dapat memberikan gratifying (kepuasan), (2) you cannot fail to make him a happy, as well as better, artinya kau yakin bahwa lewat sastra tidak akan gagal mengajak siswa bahagia dan menjadi semakin baik karakternya.

Sastra mengajak siswa untuk memahami diri dan kehidupan agar semakin bagus. Apa yang digambarkan dan disajikan kepada anak Kenya, Dembu, Jawa, dan sebagainya melalui literatur jelas merupakan refleksi kehidupan. Apa yang dilukiskan oleh masyarakat Thailand, Mianmar, Riau, Jawa, dan seterusnya merupakan gambaran hidup. Marilah kita jujur menjadi mahasiswa literatur di Kenya, Bali, Solo, Sukoharjo, Wakatobi, dan lainlain hari ini berarti sedang menjadi seorang suci. Hari ini menandai sastra itu masih hidup dan berkembang biarpun jaman sudah berubah.

Anak-anak kita diajarkan sejarah sastra Inggris, Indonesia, Amerika, Mesir, Arab, akan mengenal dunianya. Sastra juga menyebarkan nasionalisme terhadap siswa. Saya yakin bahwa prinsip-prinsip pembelajaran menunjukkan sastra dari masyarakat yang terkenal, minoritas, marginal, harus didahulukan. Sastra rakyat yang telah berjuang melawan rasisme, melawan dominasi ekonomi, hegemoni politik, dan budaya imperialis sebagian besar pada sastra di Asia dan sastra Amerika Latin, perlu diajarkan. Untuk itu kisah Hery Poter ternyata cukup membius seluruh dunia. Sastra tulis yang dipanggung dan filmkan, ternyata semakin mengenalkan dunia baru kepada siswa. Tentu tidak mungkin kalau semua bangsa harus diberi pelajaran sastra seluruh dunia, kecuali kalau studi sastra bandingan.

Sastra dari seluruh dunia dipilih dengan cara menerapkan kriteria retevan untuk perjuangan kami melawan ketidakjelasan hidup di masyarakat. Pemilihan juga dikaitkan dengan bidang kajian. Misalkan kita akan membekali siswa tentang intertekstualitas, baru dipilih sastra 
di seluruhan belahan dunia. Yang paling penting, pertimbangan estetika amat penting dalam pemilihan bahan kajian. Dalam sastra memiliki dua estetika yang berlawanan, yatu (1) estetika penindasan dan (2) estetika persetujuan pada imperialisme, Kedua estetika ini akan dipoles halus melalui berbagai ideom dan gaya bahasa sastra.

Akhirnya, saya akan mengatakan bahwa asumsi dasar yang mendasari pengajaran sastra adalah rekomendasi umum, karena muncul dari diskusi konferensi utama, bahwa literatur tidak berguna kecuali berkomitmen untuk memberikan nilai-nilai dari orang-orang bebas mengembangkan potensi. Nilai-nilai apa saja silakan dipertimbangkan demi kelancaran pengajaran sastra. Guru tentu ingin siswanya memiliki nilai lebih setelah menyelami karya sastra. Guru ingin mengajak siswa semakin maju dan beradab selama belajar sastra.

Menurut Trengove (1983:103-104) rasionalitas belajar sastra memang penting diketahui semua pihak. Menurut dia, siswa itu pada awalnya ingin membaca puisi, novel atau drama, dan seluruhnya amat bersifat personal. Dalam memahami karyakarya itu, ternyata memahami teks sama halnya sedang kooperatif dengan keinginan pengarang. Karena itu memaknai teks sama juga sedang berdialog dengan pengarang. Pengenalan sastra pada siswa agar mudah dicerna maknanya, perlu memperhatikan aspek kebutuhan. Pemikiran rasional harus selalu dikedepankan sebelum siswa bersentuhan dengan bahan ajar sastra.

Oleh sebab itu, rasionalitas amat diperlukan untuk menggiring siswa semakin asyik belajar sastra. Kunci pokok dalam rasionalitas adalah pemahaman. Sastra dihadirkan untuk dipahami secara seksama. Paham sekalis tahu, sering ditandai dengan proses internalisasi nilai. Mungkin pula siswa akan meniru beberapa tokoh dalam sastra. Biarpun sastra itu fakta imajinatif, namun bagi siswa tetap merupakan tuntunan yang berharga.

\section{Pembahasan}

\section{Kurikulum Berbasis Pengalaman}

Kurikulum berbasis pengalaman perlu dipegang teguh para guru. Sastra adalah endapan pengalaman, yang dapat menuntun siswa menuju ke arah kemajuan. Kurikulum sastra merupakan ruh pengajaran sastra. Kurikulum adalah acuan pembelajaran, hendak kemana siswa akan diajak berolah sastra. Kurikulum yang handal, yaitu apabila mampu memberikan pengalaman berharga bagi siswa. Pengalaman merupakan hal penting, untuk menabur benih apa saja lewat sastra. Para ahli sastra senantiasa mengedepankan kurikulum yang memberikan pengalaman plus pada siswa.

Pernyataan Huck Dkk (1987:12) tentang pendidikan karakter dalam sastra, seharusnya tidak diragukan lagi menjadi muatan kurikulum. Dalam kurikulum sastra perlu dieksplisitkan tentang pengalaman estetis yang mampu membentuk kepribadian. Kalau saya cermati, selama ini memang ada dua arah kurikulum sastra, yaitu (1) kurikulum yang hanya mengajak siswa membaca judul dan sejarah sastra, sehingga pengalaman intelektual semata yang diperoleh oleh siswa, (2) kurikulum pragmatik, menekankan pada aspek kegunaan sastra bagi siswa. Kurikulum yang menawarkan kajian hafalan, biasanya semakin menjauhkan siswa dari karya sastra. Berbeda dengan kurikulum yang mengejar kegunaan, semakin mendekatkan siswa pada fenomena kehidupan estetis. Studi sastra sudah sepantasnya bernilai guna, bukan membebani siswa.

Rodrigues dan Badaczewski (1978:15) menyatakan bahwa studi literatur telah menjadi andalan tradisional pengajaran bahasa di sekolah-sekolah umum sejak akhir abad kesembilan belas. Studi sastra dan bahasa adalah dua hal yang sulit dipisahkan. Dalam kurikulum pengajaran 
bahasa, selalu ada sastra, begitu juga sebaliknya. Hanya saja, memang harus diakui kurikulum sastra pada masa itu menekankan sejarah sastra, biografi penulis, dan kritik sastra, dan karya-karya seperti Silas Marner dan Julius Caesar yang dipelajari oleh semua mahasiswa. Penekanan belajar semacam ini, mengakibatkan siswa kurang bergaul langsung dengan sastra. Maka konteks belajar dengan penuh penghayatan masih jauh dari harapan. Konteks belajar sastra belum menyajikan pengalaman, melainkan masih berupa pengetahuan.

Sejak saat itu, pengajaran sastra tidak berubah begitu banyak seperti yang telah tumbuh secara mendalam dan ruang lingkupnya. Pada tahun 1917, Dewan Nasional Guru Bahasa dan Asosiasi Pendidikan Nasional mempersiapkan siswa untuk hidup, bukan hanya untuk kuliah, tetapi pada saat yang sama, panitia menganggap bahwa studi sastra klasik penting. Sastra klasik dapat menuntun siswa ke arah pencerahan hidup. Sastra klasik biasanya memuat ajaran kehidupan. Sastra klasik dapat memancing tim pengembang kurikulum agar siswa mampu menyerap nilai-nilai dalam sastra. Sastra klasik merupakan resep pengalaman masa silam yang dapat dijajdikan pegangan hidup siswa.

Pada tahun 1935 gagasan "Kurikulum Berbasis Pengalaman" (KBP) diperkenalkan, menekankan nilai sosial dari kelas bahasa dan pentingnya siswa mulai menggali pengalaman di kelas sastra. Kurikulum semacam itu sesungguhnya lebih tepat dalam pengajaran sastra, sebab karya sastra merupakan ekspresi pengalaman hidup. Sastra menyajikan aneka pengalaman yang telah diendapkan. Oleh sebab itu, belajar sastra sama halnya sedang menggali pengalaman yang unik. Guru mengajar sastra dalam hal pola, tema, dan ide-ide harus dikaitkan dengan pengalaman hidup siswa. Pengalaman apa saja dapat dimunculkan lewat sastra; pengalaman pahit, getir, dan menyenangkan.

Atas dasar hal tersebut, saya tegaskan bahwa pengalaman amat penting diserap dari sastra. Hal ini dilandasi oleh dua alasan, yaitu (1) sastra merupakan refleksi kehidupan yang berasal dari endapan pengalaman batin pengarang, (2) sastra adalah hasil imajinasi pengarang dari pengalaman hidup orang-orang di sekitarnya. Pengalaman estetis itu dapat diraih ketika kurikulum yang dibangun dapat memfasilitasi keinginan siswa. Kurikulum merupakan panduan belajar, sehingga perlu diuji relevansi dan kehandalannya. Kurikulum yang fleksibel dan kreatif, justru akan memperkaya pengalaman siswa. Lahirnya pengalaman lewat sastra akan menantang kehidupan siswa, untuk senantiasa melakukan tawarmenawar. Pengalaman yang tergarap matang dalam kurikulum semakin memperkokoh jati diri siswa.

Kurikulum pengalaman seharusnya disebarluaskan. Kurikulum tersebut akan membuka wawasan hidup. Siswa adalah orang yang membutuhkan keragaman pengalaman. Dengan cara itu, kelak mereka akan emnentukan identitas dirinya. Pada tahun 1958, Konferensi Masalah Dasar Dewan Nasional Guru Bahasa Inggris, Bahasa Asosiasi modern, American Studies Association menentukan materi studi bahasa: sastra, bahasa, dan komposisi. Konferensi ini juga membantu menekankan pentingnya kurikulum bahasa Inggris menjadi teratur dan kumulatif. Tentu saja lewat kurikulum, sastra perlu mendapat penekanan. Sastra sudah saatnya diajarkan dengan menggali pengalaman yang bervariasi.

Pada tahun 1966, Amerika melakukan konferensi pengajaran sastra. Salah satu kesimpulan utama dari konferensi adalah bahwa kelas bahasa Inggris harus membantu siswa tumbuh sebagai individu dan menekankan pada analisis sastra. 
Pertumbuhan hidup itu dapat diraih melalui kurikulum sastra yang kaya pengalaman. Dalam dekade setelah konferensi itu, keragaman menjadi karakteristik dari kelas bahasa Inggris. Keragaman dalam kurikulum adalah sebuah tawaran pengalaman hidup yang amat berharga. Melalui drama, game, belajar induktif, dan jumlah tak terhitung kelas khusus diselenggarakan di sekitar beberapa skema sastra atau orientasi keterampilan, siswa akan semakin bergairah menyelami pengalaman bersastra.

Pengalaman bersastra amat luas. Secara garis besar, pengalaman yang perlu ditetapkan dalam kurikulum ada dua hal, yaitu (1) pengalaman apresiatif, membaca langsung, dan menghargai karya sastra, (2) pengalaman memproduksi dan berkreasi, sehingga siswa benanr-benar memiliki kenikmatan bersastra. Pengajaran sastra yang menawarkan pengalaman bervariasi, akan semakin mendewasakan siswa. Tentu saja kurikulum tidak sekedar mewadahi pengalaman pasif, melainkan juga reproduktif.

\section{Guru Sastra Serba Tahu Vs Penyemai Pengalaman Hidup}

Guru memang selalu memposisikan dirinya serba tahu. Dalam pengajaran sastra, sebenarnya tidak harus demikian. Jika guru merasa belum pernah membaca karya sastra, baru mengetahui judul, lalu berbohong pada siswa, akibatnya kurang bagus. Guru itu akan memiliki sikap serba tahu, gemar ceramah melulu. Hal ini seperti pengajaran dongeng, guru seolah-olah orang pintar yang pandai mendongeng. Guru menguasai aneka kisah, hingga siswanya terpukau.

Apa pilihan yang tersedia untuk guru bahasa Inggris dalam mengajar sastra? Di mana sebaiknya guru awal dimulai? Jika guru yang berpengalaman sedang mempertimbangkan perubahan dalam struktur kurikulum, apa pilihan yang tersedia? Ini adalah beberapa pertanyaan kunci buku ini dengan harapan dapat terjawab. Salah satu tempat yang mendasari dasar dari buku ini adalah bahwa tidak mungkin untuk generalisasi tentang pendekatan yang terbaik untuk setiap kelas yang diberikan. Tiap kelas yang belajar sastra boleh jadi menggunakan pendekatan yang berbeda. Hal itu adalah keputusan guru, hanya guru yang mengetahui karakteristik kelas tertentu dan kebutuhan khusus dari para siswa.

Memang dalam pratik pengajaran sastra ada dua tipe guru, yaitu (1) guru yang otoriter, dengan semena-mena memilihkan bahan sastra, lepas anak menyukai atau tidak. Jika siswa tidak suka karya itu, justru dinilai jelek. Guru semacam ini, biasanya tidak memberi kelonggaran pada siswa. Terlebih lagi jika guru itu malas, sehingga hanya mengikuti karya yang disajikan pada buku teks atau LKS; (2) guru yang terlalu membebaskan kepada siswa, untuk memilih sendiri karya yang disukai. Bahkan guru itu juga mempersilakan siswa membaca semampunya, menurut caranya siswa. Yang dipentingkan siswa itu mau membaca karya sastra, Tujuan utama pengajaran sastra adalah membaca sastra atau menikmatinya. Oleh sebab itu, guru memang penting, tetapi bukan malaikat sastra. Guru boleh saja menawarkan karya sastra, namun tidak berarti harus bersikeras, sembarangan menentukan karya sastra.

Huck Dkk. (1987:4-5) menyarankan bahwa sastra adalah ketajaman imajinatif tentang hidup dan ajaran yang disampaikan dalam bentuk dan struktur bahasa. Pendapat ini akan membingkai tugas guru, untuk mengarahkan siswa agar sastra tetap berperan dalam kehidupan. Sastra itu fakta imajinatif. Sastra menyangkut hidup dan ajaran hidup. Namun sastra disimbolkan lewat bahasa, sehingga butuh tafsir. Guru bertugas menuntun penafsiran sastra, bukan sebaliknya mengebiri penafsiran. Sebuah pertanyaan kritis yang diajukan Huck (1987) yaitu "how do symbol produce an 
aesthetic experience?" Dia menjawab sendiri secara oratoris, bahwa symbol yang berupa pengalaman estetis itu, dapat dinyatakan sebagai good writing, manakala memperhatikan aspek (1) intelektual dan (2) emosional. Ketika sastra menggugah dua hal ini, berarti siswa akan merasa butuh belajar sastra. Guru perlu meneladani, agar siswanya terangsang untuk memetik dua pengalaman itu lewat membaca sastra.

Tujuan dari tulisan ini adalah untuk memberikan perkenalan dasar pada masingmasing pilihan yang tersedia bagi guru. Untuk menentukan potensi tujuan siswa dapat bertemu melalui studi dalam setiap opsi, untuk menyediakan berbagai strategi pengajaran bagi guru, untuk menyarankan cara mengevaluasi mahasiswa pertumbuhan dalam batas-batas pilihan tertentu, dan untuk menyarankan baik cetak dan bahan nonprint tersedia untuk kedua siswa dan guru. Setelah membaca bab ini, guru harus mampu (1) Menentukan alasan untuk mengajar sastra, (2) Mengidentifikasi cara untuk mengajar sastra secara kelompok, (3) Pilih metode individualistis belajar siswa.

Guru sastra yang ideal, tentu bukan serba tahu dan menjadi malaikat sastra. Guru juga manusia biasa, yang mungkin keliru dalam menafsirkan sastra. Oleh sebab itu, tidak adil kalau guru terlalu mengekang siswanya. Guru yang sering menyalahkan siswanya ketika memaknai karya sastra jelas tidak tepat. Apalagi sastra itu multimakna, sehingga tidak bisa disalahkan. Anggapan makna itu hanya tunggal, hanya milik guru, adalah kekeliruan pengjaran sastra yang amat fatal.

Seperti aspek lain begitu banyak program bahasa dan seni, harus menentukan apa yang harus diajarkan di kelas tertentu. Persoalannya, menurut Huck (1987), "children read books written for adult", akibatnya seringkali siswa kurang paham. Imajinasi orang dewasa sering beda dengan gagasan siswa. Itulah sebabnya bacaan sastra untuk siswa, yang berasal dari siswa, apapun wujudnya jauh lebih bagus disbanding karya orang dewasa. Yang penting lagi, siswa ada baiknya diajak memilih bahan yang akan dipelajari, bukan monopoli guru, asal yang disenangi guru.

Sastra perlu diajarkan dengan banyak pilihan, karena itu guru tidak bisa berpurapura melakukan. Yang jelas, Huck (1987) sudah mengisyaratkan bahwa "literature illuminates the human condition by shaping our insight." Sastra diajarkan dalam rangka menerangi wawasan hidup manusia. Ketajaman wawasan hidup yang muncul dari fakta imajinatif, akan memupuk kepekaan luar biasa bagi siswa. Maka, guru bahasa setidaknya harus mampu membenarkan ajaran sastra, pilihan mana yang hendak dilakukan siswa, dan metode yang mereka adopsi. Pengajaran sastra tidak cukup hanya pembenaran, melainkan harus ada aktivititas nyata.

\section{Membangun Pengalaman dari Warisan Budaya}

Sastra adalah warisan budaya. Pengarang ingin mewariskan budaya,untuk membangun peradaban manusia. Pengajaran sastra sebenarnya sebuah upaya penanaman budaya. Lewat sastra orang akan mempelajari budaya. Lewat sastra pula siswa akan belajar menjajdi manusia beradab. Peraban baru dapat dibangun dari membaca sastra. Oleh karena dalam sastra kaya contoh dan daya rangsang yang layak dijadikan tauladan hidup. Hal ini seperti dinyatakan Rodrigues dan Badaczewski (1978) menyatakan bahwa suatu realitas selama pengajaran sastra adalah senantiasa memungkinkan siswa untuk menyadari warisan budaya mereka. Seperti sekolah telah membentuk program sastra Amerika atau sastra Inggris atau beberapa variasi tersebut, tentu diupayakan untuk mempelajari budaya masyarakat termaksud. Keterkaitan satsra dengan budaya memang sangat dekat. 
Dengan cukup tegas Huck Dkk (1987:8) menyatakan "Literature should be valued in our homes and schools for enrichment it gives to the personal live of children, as well as for its proven educational contributions." Pernyataan ini memberikan taburan pemikiran, bahwa belajar sastra itu tidak akan sia-sia. Membaca sastradapat dilakukan di rumah, sekolah, dan di mana saja. Sekolah bukan satu-satunya tempat belajar sastra. Sastra dapat memperkaya pribadi. Sastra memiliki kontribusi dalam mendidik siswa ke arah manusia beradab (berbudaya). Siswa dapat menentukan horizon hidup dan menemukan pengalaman baru tentang budaya lewat sastra.

Kalau demikian, berarti belajar sastra sama halnya sedang menghayati budaya yang digambarkan lewat tokoh dan deskripsi teks. Untuk mempelajajri aspek warisan budaya, selama ini ada dua pendekatan yang paling sering digunakan yaitu (1) pendekatan kronologis dan (2) pendekatan tematik. Pendekatan kronologis mungkin lebih sistematis daripada tematik dan mungkin berhubungan dengan peristiwa sejarah dan gerakan serta perkembangan filosofis. Pendekatan tematik dapat memungkinkan siswa untuk memahami universal seluruh periode sejarah dan untuk mengembangkan rasa berhutang budi pada masa. Di antara dua pendekatan itu, mulai tahun 2013 oleh pemerintah Kemendikbud akan dikembangkan. Sayangnya, pengajaran sastra justru akan mendapat tantangan berat. Dengan dalih pemerintah ingin melakukan perampingnan kurikulum, besar kemungkinannya pengajaran sastra akan semakin terkurangi sepak terjangnya.

Pendekatan tematik yang sedang disiapkan pemerintah, tampaknya akan membelenggu pengajaran sastra. Maksudnya, sadar atau tidak sekolah akan diformat atas dasar tematik yang diatur sebelumnya. Jika hal ini terlalu berlebihan, memang akan terkesan menjadi pengajaran "cekokan". Artinya, guru menjadi kurang merdeka dalam mengajak siswa belajar, karena tema sudah diatur. Pemerintah sudah sangat kebelet, dengan nada keras kepala harus menyisipkan pengajaran sastra pada pelajaran seni budaya. Mendikbud pun telah berkali-kali mendapat kecaman, namun tetap bersikeras akan menerapkan perampingan kurikulum.

Sebenarnya gabungan antara sastra dan seni budaya bukan suatu masalah, asalkan semua pihak dapat duduk bersama, merancang pengembangan kurikulum. Pendekatan warisan budaya juga mungkin terlalu selektif dan bias budaya, sehingga mengabaikan beberapa latar belakang etnis berbagai siswa. Apakah kurikulum kelas meliputi, warisan Afrika, India, Asia, atau Amerika? Secara umum, kelemahan terbesar dari pendekatan warisan budaya adalah bahwa hal itu sering gagal untuk melibatkan pelajar sastra. Ada berbagai alas an pembenaran, mengapa sastra harus diajarkn.

Pertama, sebuah alasan untuk mengajarkan sastra adalah dengan menggunakan sastra untuk pemodelan retorika atau pengembangan bahasa. Siswa didorong untuk mengembangkan kesadaran tentang gaya dan untuk meningkatkan fleksibilitas mereka dalam bahasa yang mempekerjakan dengan memiliki alat yang lebih linguistik untuk digunakan. Guru Somr telah sangat sukses dalam menggunakan pendekatan ini dengan siswa yang dipilih. Kelemahan utama adalah bahwa banyak siswa yang tidak menjadi pembaca canggih dan karena itu tidak dapat mendeteksi nuansa gaya atau pergeseran gaya. Asumsi bahwa siswa secara otomatis akan belajar menulis dan berbicara lebih baik setelah studi sastra, perlu ditanamkan. Guru harus paham struktur latihan siswa langsung ke teknik retorika dalam literatur yang mereka baca dan memungkinkan mereka untuk berlatih. 
Kedua, kebanyakan penulis mengubah gaya mereka ketika mempelajari kata-kata dan pilihan sintaksis. Tidak diragukan lagi, para individu lebih banyak membaca, dan semakin besar kemungkinan mereka mungkin menyadari efek gaya. Tapi latihan komposisi lisan dan tertulis, bukan hanya membaca dan membahas literatur, melainkan harus digunakan untuk meningkatkan keterampilan retorika siswa.

Ketiga, mempelajari sastra dapat untuk merangsang ide-ide. Oleh karena itu, kegiatan yang tercantum dalam buku ini terutama dirancang untuk belajar siswa aktif.

Keempat, studi literatur akan membantu individu mencapai rasa identitas diri dan menjelaskan nilai-nilai mereka. Ini merupakan hasil penting, salah satu yang akan tumbuh dari keterlibatan dengan literatur, tindakan yang sangat pribadi berkaitan sastra untuk diri sendiri.

Kelima, studi literatur menyediakan variasi pengalaman pada pembaca. Di tangan seorang guru terampil, semua tujuan dapat dicapai dengan setidaknya beberapa keberhasilan. Selain itu, alasan-alasan ini dapat diterapkan dalam setiap situasi struktural.

Namun, ada asumsi tentang guru mengajar sastra yang memiliki validitas sedikit atau tidak ada. Salah satunya adalah bahwa semua siswa akan bereaksi dengan cara yang sama untuk pilihan sastra yang diberikan. Para guru yang sama yang menyatakan bahwa semua individu yang berbeda sering gagal untuk melihat implikasi terhadap pernyataan bahwa untuk kelas bahasa dan seni. Jadi, kadang-kadang kita menemukan kelas yang sama membaca teks yang sama pada waktu yang sama dan yang diharapkan untuk merespon dengan cara yang sama untuk setiap waktu. Tingkat membaca siswa, minat, nilai-nilai, dan motivasi bervariasi begitu luas bahwa tuntutan semua siswa untuk membaca pekerjaan yang sama pada waktu yang sama dan tingkat tidak akan memberikan hasil yang sama kecuali pada tingkat faktual. Namun, ketika guru ingin menekankan teknik penulisan tertentu atau menggunakan sastra sebagai model untuk pelatihan keterampilan, pendekatan ini mungkin lebih efisien.

Asumsi lain dengan validitas kecil adalah bahwa semua individu harus terkena dampak karya-spesifik "klasik".

Kunci pokok sastra sebagai warisan budaya, harus tetap dipegang teguh. Kunnci tersebut sesuai saran Huck (1987) bahwa belajar sastra harus mampu provide enjoyment, artinya memetik kesenangan. Belajar sastra yang gelisah, tidak nyaman. Belajar sastra yang geli, malah boleh. Maka geliat siswa seharusnya seperti to ride a bike, artinya seperti orang sedang belajar sepeda. Biarpun suatu saat jatuh, kaki bengkak, melecet, tapi merasa nikmat. Setiap waktu dan hari, siswa yang belajar sepeda merasa bertambah pengalaman, mulai menuntun, ngawil, mengerem, hingga lepas stang. Oleh karena itu, meskipun Amerika Serikat tidak memiliki kurikulum nasional dan meskipun orang tua dan guru akan berjuang untuk mempertahankan hak masyarakat, untuk memutuskan apa yang layak dari pendidikan bagi mahasiswa, kita masih menemukan hampir semua siswa tidak hanya membaca Shakespeare, tetapi bekerja sangat spesifik membaca Hamlet, Macteth, Julius Caesar, atau kombinasi dari ini adalah khas tarif di SMA seluruh bangsa. Apakah guru mempertanyakan yang mereka ajarkan sudah dirasakan senang dan gebira? Atau apakah mereka hanya asumsi, bahwa mereka telah "selalu" diajarkan dan terus menjadi apa yang tidak jelas? Sastra seyogyanya mewariskan budaya apa saja. Budaya bersikap dan bertindak, jelas banyak hadir dalam sastra. Blajar sastra sudah selayaknya mampu menemukan pengalaman budaya tentang (1) perjuangan hidup (struggle), (2) petualangan (adventure), dan (3) kegembiraan 
(excitement). Pendekatan klasik dan modern dalam pengajaran sastra secara langsung berkaitan dengan pendekatan warisan budaya. Yang penting, siswa merasa gemar bersastra. Kegembiraan adalak tolok ukur keberhasilan, mampu tidaknya siswa menyerap warisan budaya.

\section{Pengajaran Sastra Berbasis Pengalaman Menggoda}

Sampai hari ini,pamor pengajaran sastra masih haris "dielus-elus" terusmenerus. Maksudnya, sebagaimana sebilah keris, suatu saat perlu dibersihkan (diwarangi), agar semakin sakti dan menggoda. Pengajaran sastra yang menggoda sungguh menggiurkan semua pihak. Jika pengajaran sastra hanya "datar", monoton, cepat atau lambat akan menghapus pamor. Harus diakui, bahwa pamor pengajaran sastra dari waktu ke waktu mengalami erosi drastis. Banyak hal tentu yang menyebabkan pengajaran sastra kurang menggembirakan. Namun kalau bertumpu pada Gilroy-Scott (1983:1-4) ternyata beberapa ahli membantah bahwa telah terjadi penurunan pamor studi sastra di luar negeri, terutama dalam konteks pembelajaran bahasa. Sastra yang merasuk ke dalam bahasa, belum begitu terasa, begitu juga sebaliknya.

Sejak tahun 1945 teori pengajaran bahasa telah menarik perhatian bidang sastra. Ketertarikan ini didorong asumsi bahwa pengajaran sastra dapat mendukung pengajaran bahasa. Ketrampilan bahasa dapat dibantu oleh bidang sastra. Karena itu telah tepat menunjukkan bahwa semua penekanan terlalu sering pada pengetahuan sastra sebenarnya kurang begitu bagus. Pengetahuan sastra kurang mendukung keterampilan berbahasa. Seharusnya pengajaran sastra memposisikan diri sebagai pendorong menarik tidaknya pengajaran keterampilan bahasa.

Kecenderungan telah terkurangi, jika tidak malah hilang bahwa komponen sastra di tingkat awal dan menengah lebih berkonsentrasi pada keterampilan (1) membaca, (2) menulis dan (3) berbicara. Hal ini sering diasumsikan bahwa penguasaan bahasa, seperti yang dipahami oleh filsafat yang dominan, pada akhirnya akan menghasilkan, antara lain, pasokan mahasiswa mampu mengajar studi sastra. Ada kebutuhan yang mendesak untuk bimbingan atas pertanyaan tentang bagaimana memperkenalkan teks-teks sastra pada siswa. Dalam jangka panjang masalahnya adalah bagaimana reintegrasi dan rehabilitasi sastra sebagai bagian integral dari program bahasa. Pengajaran sastra tidak hanya untuk meminimalkan shock budaya, tetapi juga untuk mengeksploitasi potensi pengayaan pendidikan berolah sastra.

Dengan demikian tulisan dalam koleksi ini dimaksudkan untuk mempromosikan diskusi dan eksperimen apa yang sejauh ini telah diabaikan banyak orang. Mereka cenderung lebih fokus pada penerapan studi bahasa sastra. Batas studi bahasa dan sastra memang kadang-kadang kabur. Beberapa tahun terakhir studi bahasa sastra tercermin dalam kajian gaya bahasa sastra. Gaya bahasa memang berada pada posisi tengah antara bahasa dan sastra. Apalagi telah banyak dipahami bahwa penggunaan teks sastra otentik untuk pembelajaran bahasa, gaya bahasa selalu dominan dalam pembahasan. Tanda-tanda bahwa perkembangan dalam pengajaran bahasa yang komunikatif akan menghapus keberatan teoritis, patut diapresiasi. Oleh karena pengajaran teoritis hanya menjadi beban siswa. Lewat pengajaran yang komunikatif, sastra dapat berperan di dalamnya.

Agar lebih menggoda, kiranya pengajaran sastra dapat diformat dengan strategi (1) Guru sastra telah merespon masuknya siswa yang kurang siap dalam berbagai cara. Guru menjadi panutan belajar, tidak sekedar memberikan instruksi, melainkan perlu menghadapi kesalahan 
belajar sastra. Maksudnya, belajar sastra yang hanya menghafal judul dan nama pengarang jelas menjadi beban otak. (2) Bahan pelajaran sastra pun harus menggoda, sesuai dunia siswa. Respon siswa semakin tergoda apabila karya yang dibaca selaras dengan jalan hidupnya. Respon lain adalah untuk menarik perhatian pada sosio-budaya kesulitan siswa dalam menghadapi sastra asing, akan semakin kacau apabila sekedar menghafal judul dan pengarang. (3) Strategi baca langsung pada karya, jauh lebih menggoda disbanding sekedar hafalan. Apalagi kalau siswa sekedar belajar synopsis novel dan atau mempelajajri potongan sastra, akan memusingkan kepala. Argumen saat ini adalah bahwa siswa tidak dapat memahami Shakespeare tanpa terlebih dahulu mengetahui latar belakang abad ketujuh belas atau lebih sepele bahwa kita tidak dapat memahami Wordsworth jika belum pernah melihat sebuah puisi yang pernah dihasilkan. Dalam kaitan ini berarti latar belakang social budaya dan hasil karya itu penting untuk memahami totalitas makna. JIka tanpa pemahaman kedua hal itu, akan menyebabkan siswa sampai pada pelarian dari teks. Maksudnya, siswa akan tercerabut dari teks atau tidak mengenal sama sekali. Makna teks sastra tidak akan lengkap apabila sekedar ditelusuri dengan hafalan judul dan nama pengarang.

Jika memahami sastra hanya sekedar judul dan pengarang, jelas baru kulit sastra. Akibatnya, siswa tidak tahu bagaimana mendekati teks dan guru tidak tahu bagaimana untuk mempresentasikannya. Itulah sebabnya mengenal teks lebih dekat, membaca teks secara mendalam, dan mengapresiasi, semakin dibutuhkan. Pengajaran tentang sosiologi sastra, psikologi sastra, sejarah sastra, dan kritik yang berkembang tampaknya kurang meningkatkan kemampuan pembaca memahami teks, jika tanpa apresiasi secara sungguh-sungguh. Apresiasi akan mengajak siswa sampai ke tingkat menyenangi. Jadi apresiasi sastra juga menyentuh rasa, tidak sekedar pikiran belaka.

Siklus akademik kuliah sastra selama ini, memang masih jarang yang sampai melakukan apresiasi. Otoritas kritis diciptakan dan ujian selalu otoriter dalam pengajaran sastra, padahal memaknai sastra harusnya demokratis, apresiatif, dan kreatif. Fakta yang terpusat pada model pembelajaran hafalan, tampaknya sangat jauh dari apa yang secara longgar mungkin disebut sebagai tujuan asli sastra. Tujuan sastra adalah terjadi komunikasi estetis dan kreatif. Pembaca seharusnya memetik pemahaman yang menyenangkan ketika belajar sastra.

Yang dianggap sebagai tujuan sastra sangat tergantung pada status sastra di negara itu. Status sastra ada tiap wilayah sering berbeda. Ada sastra yang berstatus sebagai propaganda, iklan, dan untuk menyemaikan ajaran. Tiap bangsa boleh saja menetapkan status sastra. Sastra keratin dan sastra pedesaan tentunya berbeda tujuannya. Status sastra akan menentukan bagaimana sastra harus diajarkan. Optimalisasi belajar sastra tergantung pada apa yang hendak diraih lewat sastra. Apapun alasannya, belajar sastra semestinya berdampak pada rasa, tidak hanya pikiran.

\section{Penutup}

Atas dasar pembahasan di atas, dapat disimpulkan bahwa penyemaian pengalaman bersastra merupakan hal yang perlu dikedepankan. Basis pengalaman justru membekali kemampuan siswa menyelami hidup lewat sastra. Sastra memuat aneka tawaran pengalaman, dari hidup yang sederhana sampai hidup yang kompleks. Hidup senanntiasa penuh tantangan, sehingga kalau disikapi secara benar akan menyenenakgan.

Jika kisaran pengajaran sastra yang menyenangkan, aspek kognitif selalu 
dominan dibanding aspek afektif, tentu dianggap belum sukses. Aspek kognitif ini dikembangkan, karena ada asumsi bahwa teks-teks sastra ditulis untuk dibaca terutama oleh individu dalam privasi di rumah mereka sendiri. Kadang-kadang sastra juga perlu dipelajari secara kelompok yang seimbang antara aspek kognitif dan afektif. Keduanya harus terjadi pada pikiran siswa secara terbuka ketika membaca karya sastra. Kalau begitu, jelas gerakan ini diperlukan untuk membangun kembali hubungan yang tepat dan mendasar antara pembaca dan teks.

Jika siswa dan guru sudah merasa tergoda dan bahkan tertantang mempelajari sastra, berarti akan sukses pengajaran sastra. Pengajaran sastra yang menyajikan pilihanpilihan, bukan menghakimi, justru lebih menggoda. Sukses besar dalam pengajaran sastra terjadi manakala ada komunikasi sastra. Manakala guru dan siswa sama-sama terlibat dalam sastra, menandai keberhasilan optimal dalam pembelajaran sastra.

\section{Daftar Pustaka}

Dunning, Stephen. 1965. Teaching Literature to Adolescent; Poetry.
London: Scott, Foresman and

Company.

Endraswara, Suwardi. 2002. Metode

Pengajaran Apresiasi Sastra.

Yogyakarta: Radhita Buana. 2003.Membaca,

Menulis, dan Mengajarkan Sastra.

Yogyakarta: Kota Kembang.

Gylroy-Scott, Neil. 1983. "Introduction"

Teaching Literature Overseas. New

York: The British Council.

Howes, Alan B. 1962. Teaching Literature to Adolescent: Novels. London: Scott, Foresman and Company.

Huck, Charlote S. Dkk.1987. Children's

Literature in the Elementary School.

Tokyo: Holt, Rinehart and Winston, Inc.

Jenkinson, B dan Stauder Hawley. 1974.

On Teaching Children of Literature.

London: Bloominton Indiana

University press.

Moody, HLB. 1971. The Teaching of

Literature; with special reference to developing Countries. London: Longman.

Rodrigues, Roymond dan Dennis Badaczewski. (1978). A Guidebook for Teaching Literature. BostonLondon-Sidney: Allyn and Bacon, Inc. 